Prepared in cooperation with the Bureau of Reclamation

\title{
Update of the Accounting Surface Along the Lower Colorado River
}

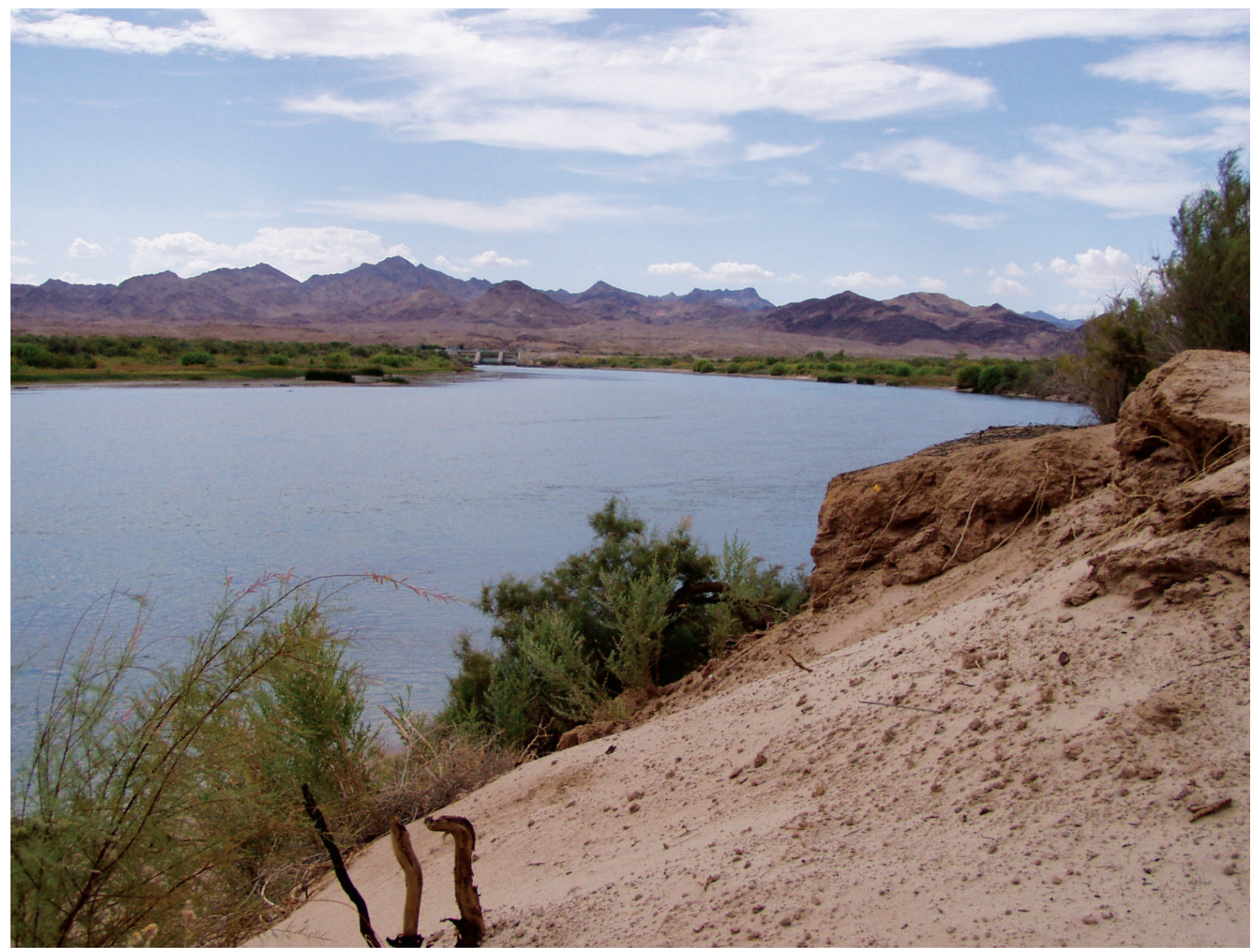

Scientific Investigations Report 2008-5113 
FRONT COVER — Looking upstream at Palo Verde Dam on the Colorado River near Blythe, California.

Photo taken by Sandra J. Owen-Joyce, July 25, 2007. 


\section{Update of the Accounting Surface Along the Lower Colorado River}

By Stephen M. Wiele, Stanley A. Leake, Sandra J. Owen-Joyce, and Emmet H. McGuire

Prepared in cooperation with the Bureau of Reclamation

Scientific Investigations Report 2008-5113 


\section{U.S. Department of the Interior \\ KEN SALAZAR, Secretary}

U.S. Geological Survey

Suzette M. Kimball, Acting Director

U.S. Geological Survey, Reston, Virginia: 2008

Revised and printed 2009, version 1.1

This report and any updates to it are available online at:

http://pubs.usgs.gov/sir/2008/5113/

For product and ordering information:

World Wide Web: http://www.usgs.gov/pubprod

Telephone: 1-888-ASK-USGS

For more information on the USGS - the Federal source for science about the Earth, its natural and living resources, natural hazards, and the environment:

World Wide Web: http://www.usgs.gov

Telephone: 1-888-ASK-USGS

Any use of trade, product, or firm names is for descriptive purposes only and does not imply endorsement by the U.S. Government.

Although this report is in the public domain, permission must be secured from the individual copyright owners to reproduce any copyrighted materials contained within this report.

Suggested citation:

Wiele, S.M., Leake, S.A., Owen-Joyce, S.J., and McGuire, E.H., 2009, Update of the accounting surface along the lower Colorado River: U.S. Geological Survey Scientific Investigations Report 2008-5113, version 1.1, 16 p., 3 plates in pocket.

Cataloging-in-publication data are on file with the Library of Congress (http://www.loc.gov/). 


\section{Contents}

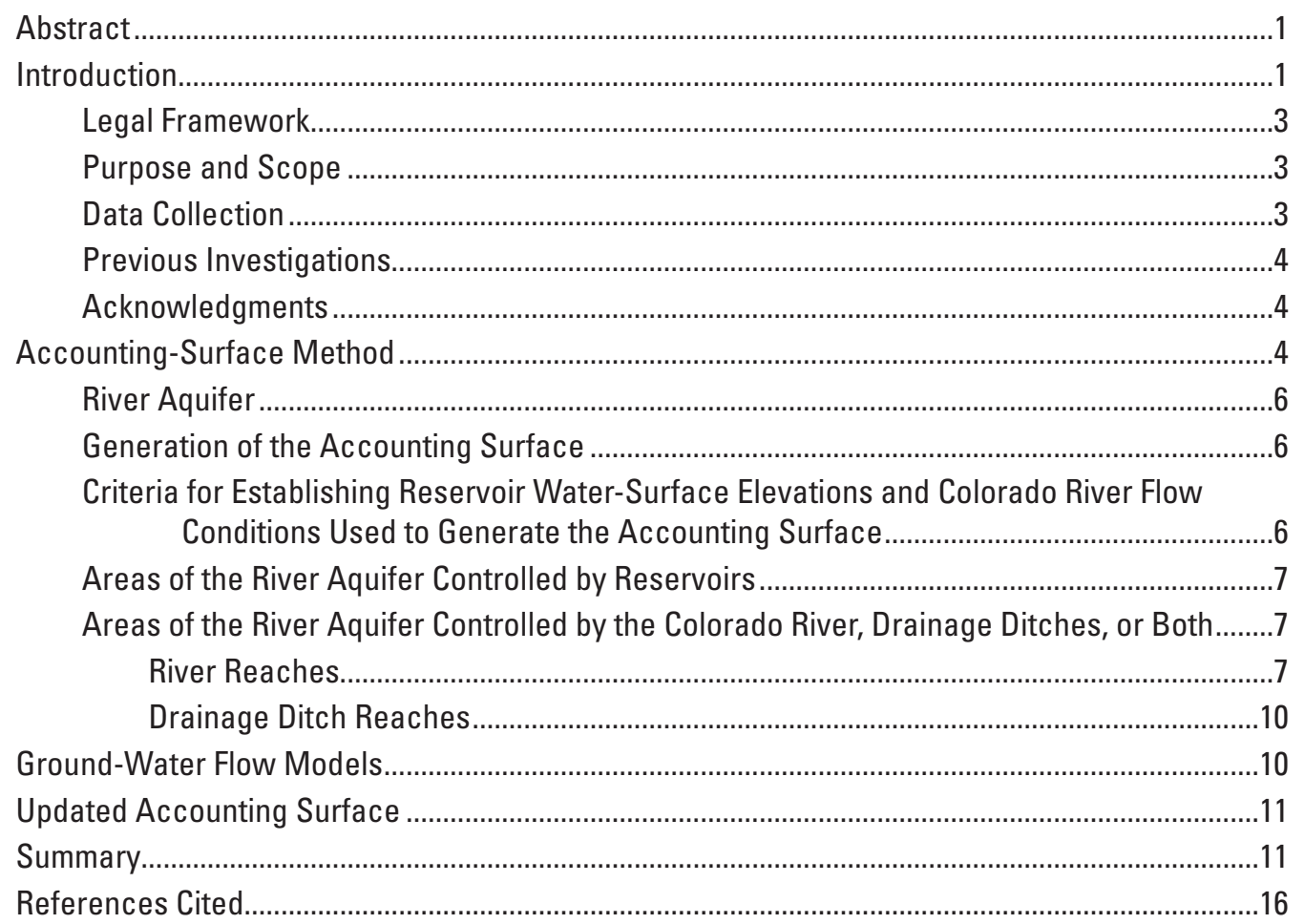

\section{Appendixes [available only online at http://pubs.usgs.gov/sir/2008/5113/appendixes]}

1. Drainage ditch water-surface elevations used in the ground-water flow model.

2. Path of the Colorado River used in the ground-water flow models.

3. Digitized surface elevations used to represent the Colorado River in the groundwater flow model south of Eleven-mile gage.

\section{Plates [in pocket]}

1. Map showing the accounting surface around Lake Mead and Lake Mohave.

2. Map showing the accounting surface around Lake Havasu and in Mohave, Parker, Palo Verde, and Cibola Valleys and in adjacent tributary areas in Arizona, Nevada, and California.

3. Map showing the accounting surface between southern Cibola Valley and the southerly International boundary and in adjacent tributary areas in Arizona and California.

\section{Figures}

1. Map showing the lower Colorado River and areal extent of the river aquifer

2. Schematic diagram showing the river aquifer and accounting surface of the lower Colorado River

3. Water surface profile of the Colorado River used in the ground-water flow models ...................7

4. Map showing the accounting surface in the areas surrounding Lake Mead Arizona, Utah, and Nevada 
5. Map showing the accounting surface in Mohave Valley and adjacent tributary areas in Arizona, California, and Nevada

6. Map showing the accounting surface in Parker, Palo Verde, and Cibola Valleys and adjacent tributary areas in Arizona and California

7. Map showing the accounting surface in the Yuma area upstream and downstream from Laguna Dam and adjacent tributary areas in Arizona and California

\section{Tables}

1. Discharges used to determine the water-surface elevation of the Colorado River used in the ground-water flow models

2. Streamflow-gaging station data used to define the water-surface elevation used in the ground-water flow models..

3. Colorado River water-surface elevation measurements used to define the water-surface elevation used in the ground-water flow models.

4. Properties of ground-water flow models used to compute the accounting surface for areas along the lower Colorado River.

\section{Conversion Factors and Datum}

Inch/Pound to SI

\begin{tabular}{lcl}
\hline \multicolumn{1}{c}{ Multiply } & By & \multicolumn{1}{c}{ To obtain } \\
\hline & Length & \\
\hline foot $(\mathrm{ft})$ & 0.3048 & meter $(\mathrm{m})$ \\
mile $(\mathrm{mi})$ & 1.609 & kilometer $(\mathrm{km})$ \\
\hline & Volume & \\
\hline acre-foot (acre-ft) & 1,233 & cubic meter $\left(\mathrm{m}^{3}\right)$ \\
acre-foot (acre-ft) & 0.001233 & cubic hectometer $\left(\mathrm{hm}^{3}\right)$ \\
\hline & Flow rate & \\
\hline foot per day (ft/d) & 0.3048 & meter per day $(\mathrm{m} / \mathrm{d})$ \\
cubic foot per second $\left(\mathrm{ft}^{3} / \mathrm{s}\right)$ & 0.02832 & cubic meter per second $\left(\mathrm{m}^{3} / \mathrm{s}\right)$
\end{tabular}

Vertical coordinate information is referenced to the "National Vertical Geodetic Datum of 1929 (NGVD 29)."

Horizontal coordinate information is referenced to the "North American Datum of 1927 (NAD 27)."

Elevation, as used in this report, refers to distance above the vertical datum. 


\title{
Update of the Accounting Surface Along the Lower Colorado River
}

\author{
By Stephen M. Wiele, Stanley A. Leake, Sandra J. Owen-Joyce, and Emmet H. McGuire
}

\section{Abstract}

The accounting-surface method was developed in the 1990s by the U.S. Geological Survey, in cooperation with the Bureau of Reclamation, to identify wells outside the flood plain of the lower Colorado River that yield water that will be replaced by water from the river. This method was needed to identify which wells require an entitlement for diversion of water from the Colorado River and need to be included in accounting for consumptive use of Colorado River water as outlined in the Consolidated Decree of the United States Supreme Court in Arizona v. California. The method is based on the concept of a river aquifer and an accounting surface within the river aquifer. The study area includes the valley adjacent to the lower Colorado River and parts of some adjacent valleys in Arizona, California, Nevada, and Utah and extends from the east end of Lake Mead south to the southerly international boundary with Mexico. Contours for the original accounting surface were hand drawn based on the shape of the aquifer, water-surface elevations in the Colorado River and drainage ditches, and hydrologic judgment. This report documents an update of the original accounting surface based on updated water-surface elevations in the Colorado River and drainage ditches and the use of simple, physically based ground-water flow models to calculate the accounting surface in four areas adjacent to the free-flowing river.

\section{Introduction}

The accounting-surface method was developed in the 1990 s by the U.S. Geological Survey (USGS), in cooperation with the Bureau of Reclamation (Reclamation), to identify wells outside the flood plain of the lower Colorado River that yield water that will be replaced by water from the river (Wilson and Owen-Joyce, 1994; Owen-Joyce and others, 2000). Prior to the development of the accounting-surface method, water pumped from many wells outside the flood plain was not included when accounting for consumptive use of river water. A method was needed to identify which wells pump water that will be replaced by water from the Colorado River and need to be included in accounting for consumptive use of Colorado River water as outlined in the Consolidated Decree of the United States Supreme Court in Arizona v. California, 547 U.S.150 (2006). The method is based on the concept of a river aquifer and an accounting surface within the river aquifer. The study area includes the valley adjacent to the lower Colorado River and parts of some adjacent valleys in Arizona, California, Nevada, and Utah and extends from the east end of Lake Mead south to the southerly international boundary with Mexico (fig. 1). Nearly 15 years have passed since the development of the original accounting surface. Prior to the issuance of a proposed rule to define the accounting procedure, an update of the accounting surface is needed for use in the process of Decree accounting for the following reasons:

1. The original accounting surface was generated on the basis of water-surface profiles of the lower Colorado River computed for the highest median monthly projected discharge for 1992-2001 and assuming delivery of full allocations of river water to users in the United States. Since that time, historical data are available that represent the current and anticipated future operation of the Colorado River for the delivery of full allocation of river water to users in the United States and treaty deliveries to Mexico.

2. The original water-surface profiles were generated with a surface-water model representing river-channel conditions surveyed between 1980 and 1988. More recent river stage information is available, and the target elevations for Lakes Mohave and Havasu have changed slightly since the original accounting surface was developed.

3. The original accounting surface in parts of the Parker and Palo Verde areas was based on water-surface elevations in drainage ditches or wells along the edge of the flood plain that represented regulated flow conditions of the late 1980s and early 1990s. Furthermore, the elevations from the drainage ditches used in the Palo Verde Valley were based on a nonstandard vertical datum, adding an error to the elevation of the accounting surface in that area.

4. Improved ground-water flow modeling is now available that will allow efficient construction of an accounting surface tied to the river in reaches not adjacent to reservoirs. An accounting surface computed with a physically 


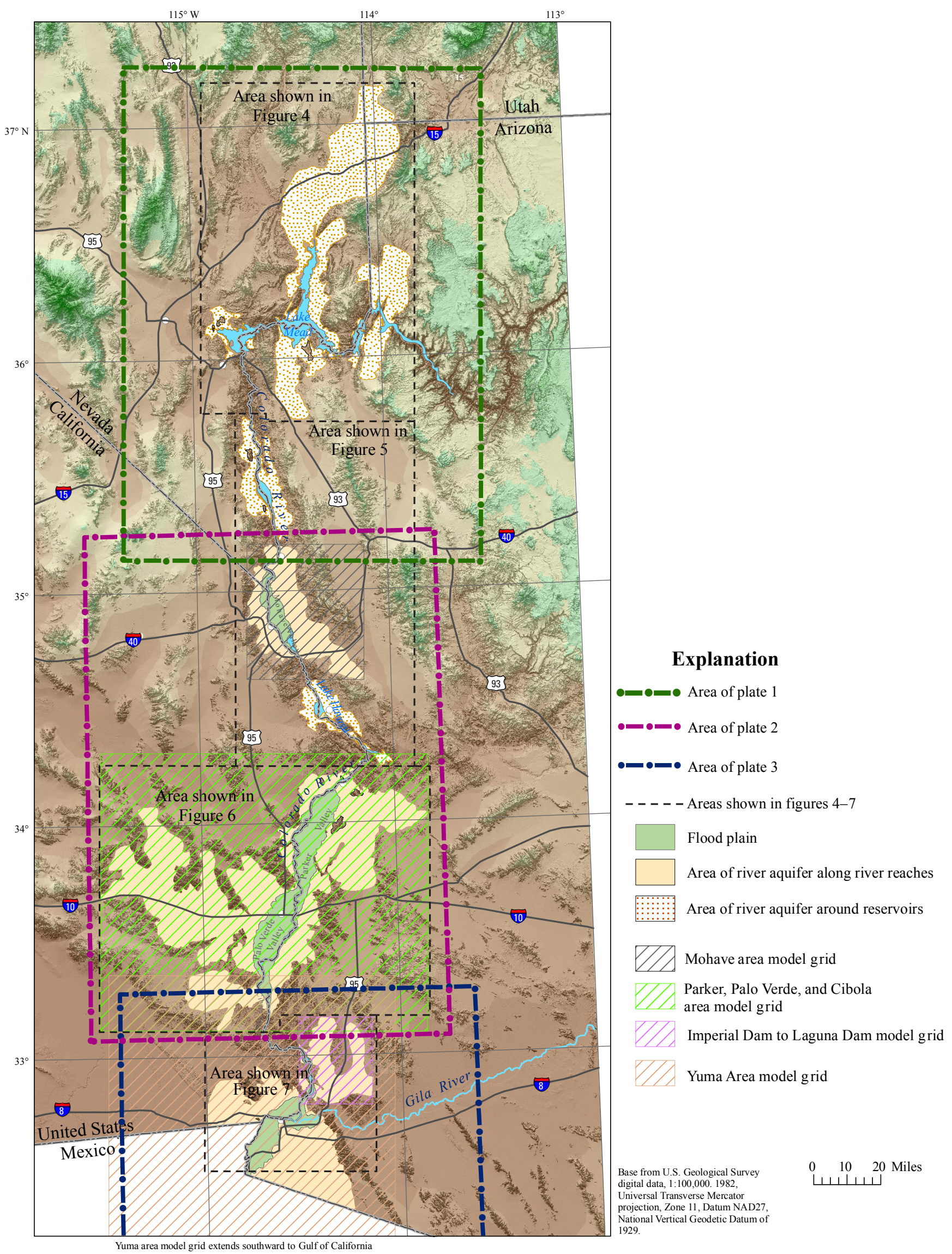

Figure 1. Map showing the lower Colorado River and areal extent of the river aquifer. 
based model is an improvement on the original accounting surface, which was hand-drawn based on hydrologic judgment, and can be easily replicated and quickly updated as required.

\section{Legal Framework}

The Colorado River Compact of 1922 apportions the waters of the Colorado River between the upper basin and the lower basin (U.S. Congress, 1948, p. A17-A22). The requirement for participation of the USGS and Reclamation is stated in Article V:

The chief official of each signatory State charged with the administration of water rights, together with the Director of the United States Reclamation Service and the Director of the United States Geological Survey shall cooperate, ex-officio:

(a) To promote the systematic determination and coordination of the facts as to flow, appropriation, consumption, and use of water in the Colorado River Basin, and the interchange of available information in such matters.

Water in the lower Colorado River is apportioned among the States of California, Arizona, and Nevada by the Boulder Canyon Project Act of December 21, 1928 (U.S. Congress, 1948, p. A213-A225) and confirmed by the Consolidated Decree (U.S. Supreme Court, 2006) in terms of consumptive use. The decree is specific about the responsibility of the Secretary of the Interior to account for consumptive use of water from the mainstream. Consumptive use is defined to include "water drawn from the mainstream by underground pumping." Article V of the Consolidated Decree (U.S. Supreme Court, 2006) states in part:

The United States shall prepare and maintain, or provide for the preparation and maintenance of, and shall make available, annually and at such shorter intervals as the Secretary of the Interior shall deem necessary or advisable, for inspection by interested persons at all reasonable times and at a reasonable place or places, complete, detailed and accurate records of: $* * *$

$* * *$ (B) Diversions of water from the mainstream, return flow of such water to the stream as is available for consumptive use in the United States or in satisfaction of the Mexican treaty obligation, and consumptive use of such water. These quantities shall be stated separately as to each diverter from the mainstream, each point of diversion, and each of the States of Arizona, California, and Nevada; ***

Article I of the decree defines terminology and states in part:

(A) "Consumptive use" means diversions from the stream less such return flow thereto as is available for consumptive use in the United States or in satisfaction of the Mexican treaty obligation;

(B) "Mainstream" means the mainstream of the Colorado River downstream from Lee Ferry within the United States, including the reservoirs thereon;

(C) Consumptive use from the mainstream within a state shall include all consumptive uses of water of the mainstream, including water drawn from the mainstream by underground pumping, and including but not limited to, consumptive uses made by persons, by agencies of that state, and by the United States for the benefit of Indian reservations and other federal establishments within the state; $* * *$

Ground water in the river aquifer beneath the flood plain is considered to be Colorado River water, and water pumped from wells on the flood plain is presumed to be river water and is accounted for as Colorado River water. Drainage ditches that lie along the edge of the flood plain contain a mixture of river water (recharged on the flood plain from the application of diverted irrigation water) and tributary water.

\section{Purpose and Scope}

This report documents the updates to the data and method used to generate the accounting surface in previous reports (Wilson and Owen-Joyce, 1994; Owen-Joyce and others, 2000) and presents the updated accounting surface needed to identify wells outside the flood plain of the lower Colorado River that yield water that will be replaced by water from the Colorado River. The report describes the process to update the accounting surface using simple, physically based ground-water flow models and contains maps (figs. 4-7 and plates 1-3) that show the elevation and contours of the updated accounting surface. Site-specific data were collected where needed to update the accounting surface.

\section{Data Collection}

The USGS collected hydrologic data for the study during 2007-08. Most field work was done along the drainage ditches on the flood plain in Parker and Cibola Valleys in Arizona, in Palo Verde Valley in California, and in the Yuma area in Arizona and California. Additional data were collected along reaches of the river between Parker and Headgate Rock Dams and from upstream of Imperial Dam to the northerly international boundary (NIB) with Mexico. Water-surface elevations in drainage ditches were determined by use of Global Positioning System (GPS) surveys (Remondi, 1985). The data are stored in a database of the Arizona Water Science Center of the U.S. Geological Survey, Tucson, Arizona.

Precise GPS was used to collect water-level elevation data in the drainage ditches of agricultural areas along the 
lower Colorado River in Parker, Cibola, and Palo Verde Valleys and in the Yuma area. Field collection of data for the Palo Verde Valley drainage-ditch survey was conducted during the weeks of August 13 and 27, 2007. Data for the drainage ditches in Parker Valley were collected during the weeks of August 27 and September 10, 2007. Data for the Cibola Valley drainage ditches were collected during the week of November 5, 2007. Data for the drainage ditches in the Yuma area were collected January 30-31, 2008. Precise GPS was also used to collect data for specific reaches along the Colorado River. Data for the river between Parker Dam and Headgate Rock Dam were collected January 24, 2008. Data for the river in the Yuma area were collected the week of February 4, 2008.

Survey methods included collecting survey data by using Real-Time Kinematic (RTK)-Infill and static GPS. RTK GPS was used to collect edge-of-water or staff-gage elevations in the drainage ditches. RTK base-station positions were located at higher topographic locations near the drainage ditches. The base-station positions were selected by virtue of line-of-sight capability with the area of the drainage ditch to be surveyed. Because most survey points within the drainage ditches were obscured from the base station by the embankments, two technicians conducted the survey for safety and to ensure lineof-site radio link between the RTK base station and rover unit. One technician entered the drainage ditch to place the rover GPS antenna pole at the edge of water or, when available, on top of a staff gage, while the second technician remained at the top of the drainage ditch with the rover radio receiver. Downto-water measurements were made from the top-of-staff gage or other measuring-point positions.

Static GPS methods included the occupation of surrounding survey benchmarks that have coordinates published by the National Geodetic Survey (NGS). Data collected from the static occupations were used to tie-in, correct, and check the coordinates of individual RTK base-station positions for each of the individual drainage-ditch surveys. In addition, individual base-station positions from each of the drainage ditches were surveyed to a single benchmark located just west of the right bank cableway tie-back at the Colorado River below Palo Verde Dam (USGS 09429100) streamflow-gaging station. Selected top-of-staff measuring points and surrounding NGS benchmarks, when available, were reoccupied with RTK GPS to check for survey accuracy and repeatability. The accuracy of the surveyed elevations was \pm 0.20 feet.

Various precise GPS methods were used to collect waterlevel elevation data depending on the conditions that existed in those areas. Traditional RTK and faststatic techniques were not feasible due to line-of-sight problems and the absence of an established faststatic base station in the area between Parker and Headgate Rock Dams. Data were collected at eleven points along this reach of the river by treating each point as a base station and obtaining an Online Positioning User Service (OPUS) solution for each point. In the Yuma area, where there is an established base station surveyed in at the Yuma USGS office, data were collected at 28 points in drainage ditches and at 6 wells using the faststatic technique. Along the river in the reach upstream from Laguna Dam, 15 elevation points were collected by using the faststatic technique with the Yuma base station at the USGS office. Along the river in the Yuma area downstream from Laguna Dam to the NIB with Mexico, the RTK technique was used to collect data at 14 points by using both the AMVD and COCO base stations, which are developed benchmarks established by the City of Yuma.

\section{Previous Investigations}

The accounting-surface method is described for two areas in separate reports - the area upstream from Laguna Dam in Wilson and Owen-Joyce (1994) and the area downstream from Laguna Dam in Owen-Joyce and others (2000). Previous geohydrologic studies of the lower Colorado River valley from Davis Dam to Yuma defined and described the formations that constitute the river aquifer, discussed the geologic structures and framework of the lower Colorado River valley, and described the occurrence and movement of ground water (Metzger, 1965, 1968; Metzger and Loeltz, 1973; Metzger and others, 1973; Olmsted and others, 1973). The major emphasis of these studies was the ground-water flow system beneath the flood plain and its relation to the Colorado River because few wells were available outside the flood plain to provide water levels or samples for chemical analysis. Refinement of the hydrogeologic framework, updated maps of ground-water flow, estimates of ground-water storage in the mound under Yuma Mesa, water-chemistry analyses, and water-budget components are topics covered in a recent study of the Yuma area (Dickinson and others, 2006). Additional work to develop procedures to apply the accounting-surface method to water-level data from wells applied geographic information system (GIS) methods to identify areas where wells pump water that will be replaced by water from the Colorado River (Spangler and others, 2007).

\section{Acknowledgments}

Jeffrey C. Addiego, Douglas B. Blatchford, William B. Greer, Ruth M. Thayer, Shana G. Tighi, and Dennis E. Watt of the Bureau of Reclamation provided information regarding discharges and water-surface profiles in the Colorado River and guidance concerning the use of drainage ditches in the ground-water modeling. The Colorado River Indian Tribes kindly provided access to their reservation. Palo Verde Irrigation District provided maps and water-level data for their staff gages in drainage ditches.

\section{Accounting-Surface Method}

The accounting-surface method was developed to identify wells outside the flood plain of the lower Colorado River that yield water that will be replaced by water from the river (Wilson and Owen-Joyce, 1994; Owen-Joyce and others, 2000). The method is based on the concept of a river aquifer 
and an accounting surface within the river aquifer. The method provides a uniform criterion for all users pumping water from wells by determining whether the elevation of the static water table at a well is above or below the accounting surface. The elevation of the static water table at a well is determined by measuring the elevation of the static water level in the well. The static water level is the level of the water in a well that is not being affected by ground-water withdrawal or the level to which water will rise in a tightly cased well under its full pressure head. Wells that have a static water-level elevation equal to or below the accounting surface are presumed to yield water that will be replaced by water from the river. Wells that have a static water-level elevation above the accounting surface are presumed to yield water that will be replaced by water from precipitation and inflow from tributary valleys (fig. 2). Ground water in the river aquifer beneath the flood plain is considered to be Colorado River water regardless of water levels. Water pumped from wells on the flood plain is presumed to be river water and is accounted for as Colorado River water.

The accounting surface is defined to represent the elevation and slope of the static water table in the river aquifer outside the flood plain and the reservoirs of the Colorado River that would exist if the water in the river aquifer were derived only from the river (Wilson and Owen-Joyce, 1994). The accounting surface extends outward from the edges of the flood plain or a reservoir to the subsurface boundary of the river aquifer. Initial attempts to compare the water level in wells to the accounting surface were stymied by the inability to obtain water levels in every well (Spangler and others, 2007). Consequently, a method was devised by Spangler and others (2007) to estimate the water surface from available data and a new category - near the accounting surface — was added to the existing categories of well water levels - at, below, or above the accounting surface. GIS methods were used to create maps from measured water-level data that were then used to delineate areas where the water levels in wells were above or below the accounting surface. Estimations of water elevation can be made for wells without a measured water level (Spangler and others, 2007) from these maps. Water levels in wells were measured with calibrated steel or electrical tapes that are accurate to within tenths or hundredths of a foot. A differential GPS was used to determine land-surface elevations to within an operational accuracy of $\pm 0.43 \mathrm{ft}$, resulting in calculated water-level elevations having a 95-percent confidence interval of $\pm 0.84 \mathrm{ft}$. GIS interpolation tools were used to delineate areas within the river aquifer where water-level elevations are presumed to be above, below, and near (within $\pm 0.84 \mathrm{ft}$ at the 95 -percent confidence interval) the elevation of the accounting surface.

The criterion in the accounting-surface method for all users pumping water from wells was changed by Spangler and others (2007) to determining whether the elevation of the static water table at a well is above, near, or below the accounting surface. Wells that have a static water-level

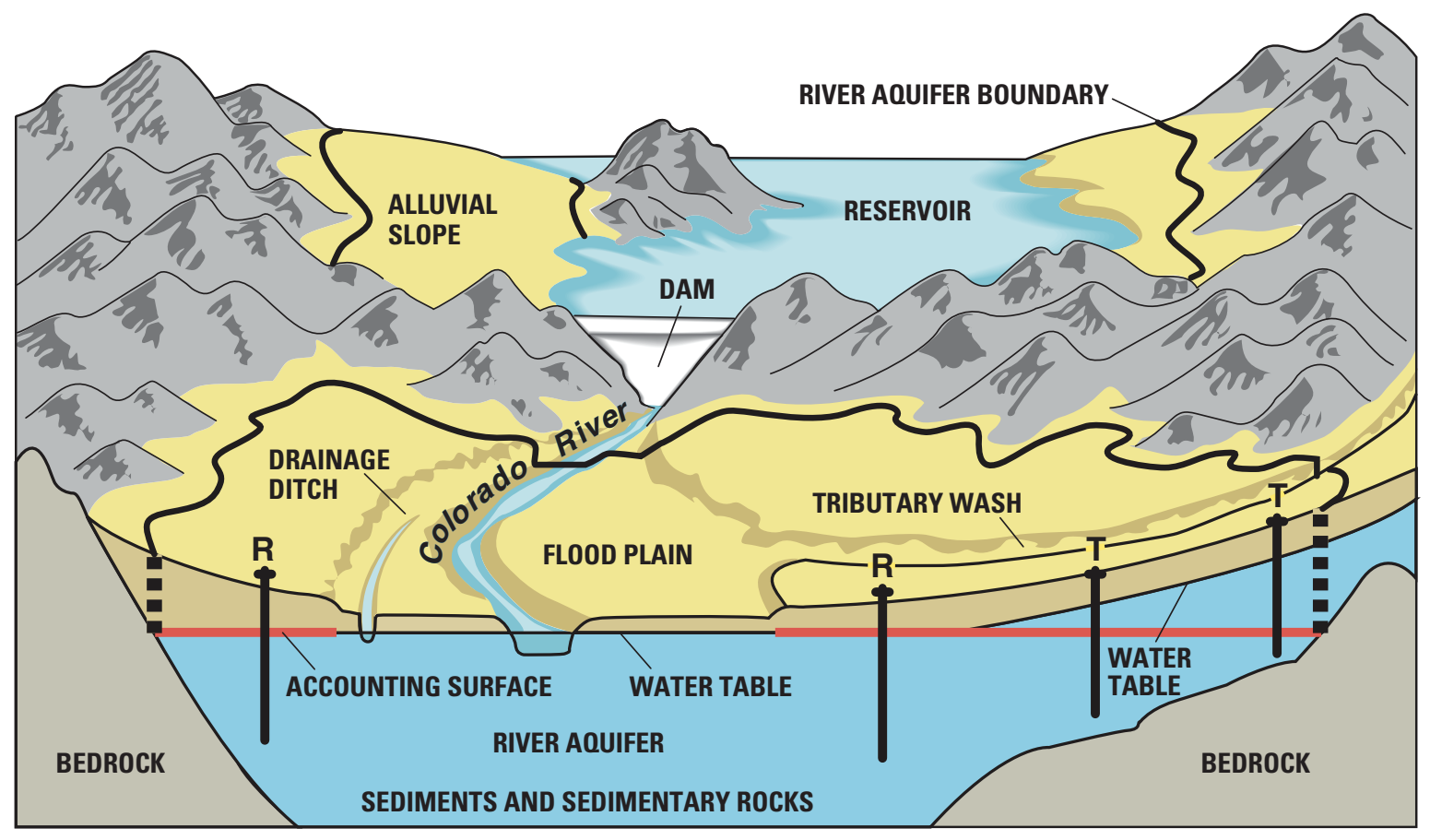

Figure 2. Schematic diagram showing the river aquifer and accounting surface (red line) of the lower Colorado River. Wells labeled " $R$ " have a static water-level elevation equal to or below the accounting surface and are presumed to yield water that will be replaced by water from the river. Wells labeled " $T$ " have a static water-level elevation above the accounting surface and are presumed to yield water that will be replaced by water from precipitation and inflow from tributary valleys (Modified from Wilson and Owen-Joyce, 1994). 
elevation near, equal to, or below the accounting surface are presumed to yield water that will be replaced by water from the river. Wells that have a static water-level elevation above the accounting surface are presumed to yield water that will be replaced by water from precipitation and inflow from tributary valleys.

\section{River Aquifer}

The boundary of the area that contains the accounting surface was defined as the river aquifer and delineated in the previous studies (Wilson and Owen-Joyce, 1994; Owen-Joyce and others, 2000). The river aquifer consists of permeable, partly saturated sediments and sedimentary rocks that are hydraulically connected to the Colorado River so that water can move between the river and the aquifer in response to withdrawal of water from the aquifer or differences in water-level elevations between the river and the aquifer. The subsurface limit of the river aquifer is the nearly impermeable bedrock of the bottom and sides of the basins that underlie the Colorado River valley and adjacent tributary valleys, which is a barrier to groundwater flow. For this study the boundary of the river aquifer remains the same as defined previously (fig. 1).

The river aquifer beneath the area where the accounting surface exists can be divided into two areas. The first area is where the water table is controlled by reservoirs, and the second area is where the water table is controlled by the Colorado River, drainage ditches on the flood plain, or both. In areas controlled by reservoirs, the accounting surface is set at a constant elevation defined by a representative reservoir level specified by Reclamation. In areas controlled by the Colorado River, drainage ditches, or both, the accounting surface varies depending on the shape of the aquifer and the surface-water elevations.

\section{Generation of the Accounting Surface}

The accounting surface adjacent to free-flowing reaches of the river between reservoirs published by Wilson and Owen-Joyce (1994) and Owen-Joyce and others (2000) was represented by hand-drawn contours based on surface-water profiles. In Parker and Palo Verde Valleys, drainage ditches or wells along the edge of the flood plain were used to define the level of the accounting surface. Reclamation considers the water levels in the drainage ditches to represent the level of Colorado River water beneath the flood plain. Adjacent to reservoirs, the accounting surface is flat, and is set to an elevation of the adjacent reservoir defined by the annual high water-surface elevation used by Reclamation to operate the reservoirs under normal flow conditions.

The general strategy for updating the accounting surface was as follows:

1. The extent of the river aquifer and area over which the accounting surface was defined by Wilson and OwenJoyce (1994) and Owen-Joyce and others (2000) was retained.
2. Water-surface profiles of the Colorado River and drainage ditches used in defining the accounting surface were updated using the most recent information available. Drainage ditches were used in Parker, Palo Verde, and Cibola Valleys in defining the accounting surface.

3. Water-surface elevations in reservoirs were updated on the basis of current operating conditions for Lakes Mead, Mohave, and Havasu.

4. Contours of the accounting surface adjacent to freeflowing reaches of the Colorado River were generated using simple steady-state ground-water models that simulate two-dimensional flow, using a constant transmissivity value, with river and drainage-ditch elevations as boundary conditions.

The discharges along the free-flowing reaches of the Colorado River and the water-surface elevations in reservoirs used to define the accounting surface were specified by Reclamation. Implementation of this general strategy is discussed in more detail in the following sections.

\section{Criteria for Establishing Reservoir Water-Surface Elevations and Colorado River Flow Conditions Used to Generate the Accounting Surface}

The water-surface elevations in the Colorado River, reservoirs, and drainage ditches satisfy the following criteria (Jeffrey C. Addiego, Bureau of Reclamation, written commun., 2007):

- The Colorado River is flowing under normal operating conditions. Normal operating conditions exist when releases from the reservoirs are being made to accommodate downstream requirements where each State is using its full apportionment (consumptive use in Arizona + California + Nevada equals 7.5 million acre-feet) and a treaty-specified 1.5 million acre-feet is being delivered to Mexico (approximately 1.36 million acre-feet at the NIB with Mexico and 0.14 million acre-feet at the land boundary near San Luis). Flow and (or) river stage values can be either historical or modeled values, and should exclude flood flows from the lower basin tributaries and side-wash inflows.

- The hydraulic influence of the Colorado River under normal operating conditions is defined by the mean stage of the Colorado River (excluding reservoirs) during the highest flow month of the year (the flow that should be used to calculate the river stage is the mean monthly flow for the highest flow month of the year).

- The elevations used for the reservoirs (Lakes Mohave and Havasu) are the high monthly target elevation for the year used when operating under normal operating conditions - 644 feet for Lake Mohave and 448.7 feet for Lake Havasu. 
- The maximum elevation of the accounting surface for Lake Mead is the top of the spillway gates in their fixed (down) position (1,205.4 feet). This elevation corresponds to an elevation (and corresponding area) in the vicinity of Lake Mead where a well would have the potential to pump Colorado River water. Whether a well would be considered to pump Colorado River water in the Lake Mead area would depend upon the actual lake elevations during the accounting year.

- The flows and river stage values account for major diversions from and return flows to the river at their respective locations. These diversions and return flows include, at minimum, the diversion at Headgate Rock Dam and major drainage ditches from the Colorado River Indian Reservation, the diversion at Palo Verde Diversion Dam and major drainage ditches from the Palo Verde Irrigation District, the diversions from Lake Havasu by the Central Arizona Project and the Metropolitan Water District canals, the diversions at Imperial Dam and major returns below Imperial Dam. As many diversions and return flow points are used as practical given the available data and the practical influence upon the resultant values.

\section{Areas of the River Aquifer Controlled by Reservoirs}

The accounting surface elevations in the river aquifer surrounding Lake Havasu, Lake Mohave, and Lake Mead are determined by the reservoir levels. Reclamation has determined that the accounting-surface elevations are $448.7 \mathrm{ft}$ for Lake Havasu, $644.0 \mathrm{ft}$ for Lake Mohave, and $1205.4 \mathrm{ft}$ for Lake Mead.

\section{Areas of the River Aquifer Controlled by the Colorado River, Drainage Ditches, or Both}

\section{River Reaches}

Along reaches of the Colorado River without irrigation on the flood plain where the river loses water to the aquifer, the accounting surface is determined by the water surface of the Colorado River. Under predevelopment conditions and where the flood plain is not irrigated with diverted river water, groundwater levels in areas outside the flood plain that are higher than the Colorado River are caused only by tributary ground-water inflow. In this case, the river controls the elevation of the water table under the flood plain, and the accounting surface would be lower than the higher water level caused by tributary groundwater inflow. Water pumped from a well with a static water level above the accounting surface would be deemed tributary water, and an entitlement would not be needed.

A calibrated and documented step-backwater model was not available for the study area, and development of such a model was beyond the scope of this study. Reclamation
Table 1. Discharges used to determine the water-surface elevation of the Colorado River used in the ground water-flow models.

[River miles start at the southerly international boundary with Mexico and increase upstream (Bureau of Reclamation, 2001)]

\begin{tabular}{lcc}
\hline \multicolumn{1}{c}{$\begin{array}{c}\text { Colorado River } \\
\text { gaging station }\end{array}$} & $\begin{array}{c}\text { River } \\
\text { mile }\end{array}$ & $\begin{array}{c}\text { Discharge, in } \\
\text { cubic feet per } \\
\text { second }\end{array}$ \\
\hline Below Hoover Dam & 342.0 & 17,634 \\
Below Davis Dam & 275.5 & 17,069 \\
At Big Bend & 264.7 & 19,567 \\
Below Parker Dam & 192.2 & 12,370 \\
Forebay at Headgate Rock Dam & 177.7 & 11,402 \\
At Parker & 175.3 & 11,970 \\
At Water Wheel & 151.5 & 11,157 \\
Below Palo Verde Diversion Dam & 132.7 & 10,924 \\
At Taylor Ferry & 106.4 & 9,825 \\
At Lower Cibola Bridge & 86.9 & 10,399 \\
Above Imperial Dam & 49.2 & 10,222 \\
Below Imperial Dam & 49.2 & 549 \\
Below Laguna Dam & 41.7 & 716 \\
Below Yuma Main Canal Wasteway & 29.4 & 1,527 \\
\hline
\end{tabular}

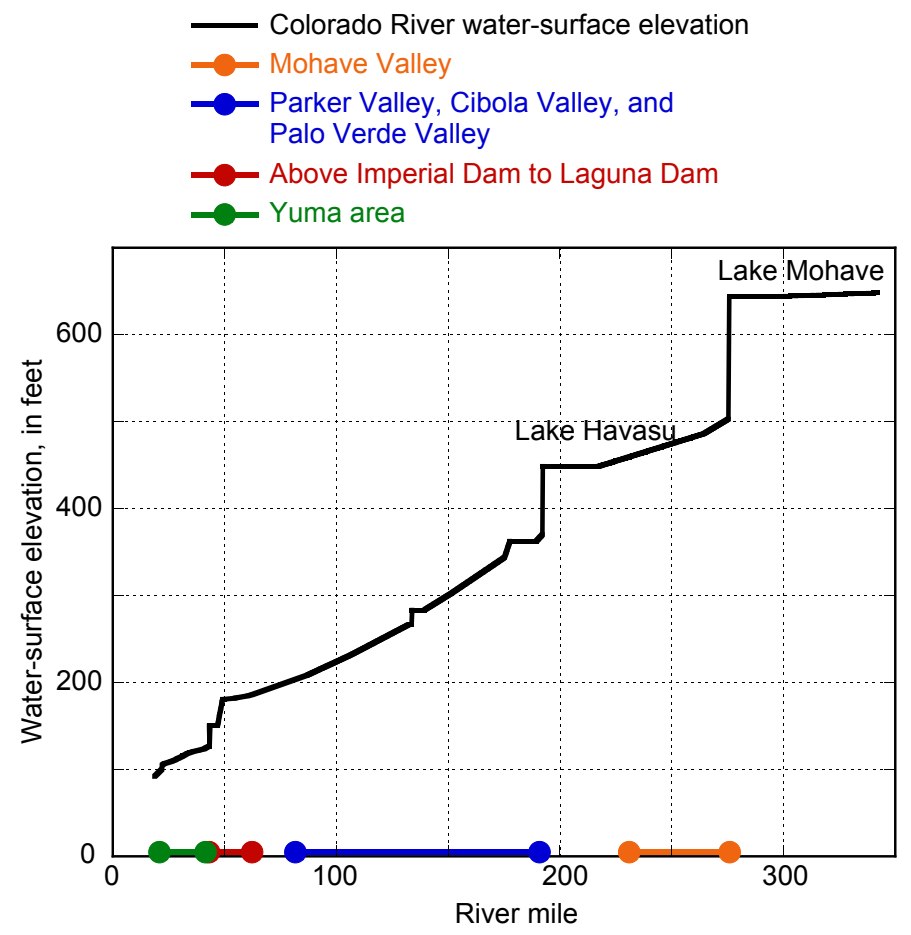

Figure 3. Water surface profile of the Colorado River used in the ground-water flow models. The approximate extent of the accounting surface in each of the four modeled areas is also displayed as a function of river mile. River miles (Bureau of Reclamation, 2001) start at the southerly international boundary with Mexico and increase upstream. 
Table 2. Streamflow-gaging station data used to define the water-surface elevation used in the ground-water flow models.

[Agency: USGS, U.S. Geological Survey; Reclamation, Bureau of Reclamation; IBWC, International Boundary and Water Commission]

\begin{tabular}{|c|c|c|c|c|c|}
\hline \multirow{2}{*}{$\begin{array}{l}\text { Colorado River } \\
\text { gaging station }\end{array}$} & \multicolumn{2}{|c|}{ UTM coordintate ${ }^{1}$, in meters } & \multirow{2}{*}{$\begin{array}{l}\text { Elevation, } \\
\text { in feet }\end{array}$} & \multirow{2}{*}{ River mile } & \multirow{2}{*}{ Agency } \\
\hline & Easting & Northing & & & \\
\hline Below Davis Dam (09423000) & 721369 & 3895914 & 503.17 & 275.40 & USGS \\
\hline Big Bend & 717750 & 3884573 & 486.60 & 264.70 & Reclamation \\
\hline Below Needles Bridge & 721649 & 3855318 & 462.20 & 243.30 & Reclamation \\
\hline RS41 (below Topock Marsh) & 731394 & 3844023 & 454.14 & 233.60 & Reclamation \\
\hline Below Parker Dam (09427500) & 763366 & 3798537 & 370.45 & 192.20 & USGS \\
\hline Forebay at Headgate Rock Dam & 750315 & 3783939 & 362.62 & 177.70 & Reclamation \\
\hline Parker & 748190 & 3781783 & 344.00 & 175.30 & Reclamation \\
\hline Water Wheel & 728171 & 3756367 & 302.63 & 151.50 & Reclamation \\
\hline Below Palo Verde Diversion Dam & 732289 & 3732777 & 267.02 & 132.70 & Reclamation \\
\hline Taylor Ferry (TFLC) & 720531 & 3701245 & 231.57 & 106.40 & Reclamation \\
\hline Lower Cibola Bridge & 716492 & 3676582 & 208.38 & 86.90 & Reclamation \\
\hline Below Imperial Dam (09429500) & 736985 & 3640727 & 180.72 & 49.20 & USGS \\
\hline Below Laguna Dam (0942600) & 732742 & 3633016 & 127.06 & 41.7 & USGS \\
\hline Below Yuma Main Canal Wasteway (09521100) & 720849 & 3623858 & 113.22 & 29.50 & USGS \\
\hline Above Rockwood Weir & 713707 & 3622116 & 106.80 & 23.10 & IBWC \\
\hline Above Morelos Dam & 712976 & 3620783 & 105.00 & 22.10 & IBWC \\
\hline Below Morelos Dam & 712939 & 3620723 & 100.20 & 22.11 & IBWC \\
\hline Eleven-mile gage & 711163 & 3616163 & 92.20 & 18.80 & IBWC \\
\hline
\end{tabular}

${ }^{1}$ Universal Transverse Mercator, Zone 11 coordinates, North American Datum of 1927.

reevaluated the discharges below dams and streamflow-gaging stations along the river used to establish the water-surface elevations according to the criteria described above (Douglas B. Blatchford, Bureau of Reclamation, written commun., 2007) and produced the discharges in table 1 . The watersurface profile of the Colorado River was based on a profile linearly interpolated between streamflow-gaging stations that was provided by Reclamation (Shana G. Tighi, written commun., 2008) that included streamflow data collected at gaging stations operated by Reclamation, USGS, and the International Boundary and Water Commission (IBWC). That profile was modified by additional water-surface elevation measurements made by the USGS. Water-surface measurements were made where the linearly interpolated profile deviated significantly from the profiles used in the previous studies (Wilson and Owen-Joyce, 1994; Owen-Joyce and others, 2000). The watersurface profile of the Colorado River used in the ground-water flow models is shown in figure 3. Data from streamflowgaging stations and USGS measurements are listed in tables 2 and 3. Tables containing the water-surface elevations in the drainage ditches, the path of the Colorado River in Universal Transverse Mercator (UTM) coordinates, and the digitized surface elevations used to represent the Colorado River south of Eleven-mile gage are in the appendixes (available only online at http://pubs.usgs.gov/sir/2008/5113/appendixes/).

Mohave Valley - The water-surface profile was determined from the stage-discharge relations at four streamflowgaging stations at river miles 275.4 (Colorado River below Davis Dam), 264.7 (Colorado River at Big Bend), 243.4 (Colorado River below Needles Bridge), and 233.6 (Colorado River near Topock [at RS41]), and the elevation of Lake Havasu.

Parker Valley and Palo Verde Valley-The linearly interpolated profile was based on streamflow-gaging station data at river miles 192.2 (Colorado River below Parker Dam), 177.7 (Colorado River Forebay above Headgate Rock), 175.3 (Colorado River at Parker), 151.5 (Colorado River at Water Wheel), 132.7 (Colorado River below Palo Verde Diversion Dam), 106.4 (Colorado River at Taylor Ferry), and 86.9 (Colorado River at Lower Cibola Bridge) and Reclamation GIS coverages of the extent of the Palo Verde Dam and Headgate Rock Dam forebays (Shana Tighi, Bureau of Reclamation, written commun. 2008). Water-surface elevation measurements were made between 
Table 3. Colorado River water-surface elevation measurements used to define the water-surface elevation used in the ground-water flow models.

\begin{tabular}{|c|c|c|c|}
\hline \multirow{2}{*}{ River mile } & \multicolumn{2}{|c|}{ UTM Coordinates ${ }^{1}$, in meters } & \multirow{2}{*}{$\begin{array}{c}\text { Elevation, } \\
\text { in feet }\end{array}$} \\
\hline & Easting & Northing & \\
\hline 191.74 & 763447 & 3798135 & 368.3 \\
\hline 190.77 & 763714 & 3796614 & 367.1 \\
\hline 189.00 & 763681 & 3794281 & 362.2 \\
\hline 188.56 & 763001 & 3794254 & 365.1 \\
\hline 187.31 & 761528 & 3793982 & 365.0 \\
\hline 186.14 & 760340 & 3793027 & 364.9 \\
\hline 184.34 & 758613 & 3790855 & 365.2 \\
\hline 182.92 & 757106 & 3789138 & 365.0 \\
\hline 181.33 & 755824 & 3787245 & 364.8 \\
\hline 179.68 & 754201 & 3785508 & 364.8 \\
\hline 178.07 & 752000 & 3784263 & 365.0 \\
\hline 47.86 & 736669 & 3639365 & 156.2 \\
\hline 47.72 & 736624 & 3639178 & 150.8 \\
\hline 46.81 & 736281 & 3638125 & 150.8 \\
\hline 44.43 & 735168 & 3635338 & 150.8 \\
\hline 40.98 & 731882 & 3631582 & ${ }^{2} 122.9$ \\
\hline 38.47 & 731591 & 3627923 & ${ }^{2} 121.3$ \\
\hline 35.93 & 731039 & 3624107 & ${ }^{2} 119.8$ \\
\hline 34.46 & 729226 & 3622800 & ${ }^{2} 118.6$ \\
\hline 34.31 & 728990 & 3622783 & ${ }^{2} 118.4$ \\
\hline 33.39 & 727531 & 3622993 & ${ }^{2} 117.7$ \\
\hline 31.55 & 724802 & 3623457 & ${ }^{2} 114.7$ \\
\hline 31.41 & 724567 & 3623385 & ${ }^{2} 114.8$ \\
\hline 30.98 & 723908 & 3623357 & ${ }^{2} 114.1$ \\
\hline 29.70 & 721982 & 3623768 & ${ }^{3} 112.0$ \\
\hline 28.88 & 720667 & 3623899 & ${ }^{3} 111.1$ \\
\hline 28.20 & 719580 & 3623936 & ${ }^{3} 110.1$ \\
\hline 26.69 & 717318 & 3624355 & ${ }^{3} 108.5$ \\
\hline 25.83 & 716056 & 3624828 & ${ }^{3} 107.7$ \\
\hline
\end{tabular}

${ }^{1}$ Universal Transverse Mercator, Zone 11 coordinates, North American Datum of 1927.

${ }^{2}$ These elevations were increased by $0.8 \mathrm{ft}$ for use in the ground-water model to account for difference in discharge specified for the accounting surface and the discharge during the stage measurements. See the section Yuma Area for further explanation.

${ }^{3}$ These elevations were increased by $1.2 \mathrm{ft}$ for use in the ground-water model to account for difference in discharge specified for the accounting surface and the discharge during the stage measurements. See the section Yuma Area for further explanation.
Parker Dam and Headgate Rock Dam during this study because the interpolated profile showed the forebay behind Headgate Rock Dam extending upstream to around river mile 189, whereas the earlier profile had a sloping water surface, resulting in higher water-surface elevations. The measurements supported the extent of the forebay represented in the interpolated profile.

Above Imperial Dam to Laguna Dam-The linearly interpolated profile was based on a streamflow-gaging station at river mile 49.2 (Colorado River below Imperial Dam) and Reclamation GIS coverages of the Imperial and Laguna Dam forebays. Water-surface elevation measurements were made above Imperial Dam and showed that the linearly interpolated profile overestimates the extent of the forebay. The measurements, which show a sloping water surface, were used in the ground-water model. The measurements were made at a discharge of about $6,000 \mathrm{ft}^{3} / \mathrm{s}$, whereas the discharge specified for the accounting surface in this reach was 10,222 ft $\mathrm{ft}^{3} / \mathrm{s}$. Stage-discharge relations were not available for this reach and a correction for the difference between the two discharges was not made. Water-surface measurements made between Imperial Dam and Laguna Dam supported the linearly interpolated profile drawn from the Reclamation GIS coverage of the Laguna Dam forebay.

Yuma area-The following six streamflow-gaging stations were used for this reach: Colorado River below Laguna Dam, below Yuma Main Canal Wasteway, above Rockwood Weir at the NIB (International Boundary and Water Commission (IBWC) 095-219.00), immediately above Morelos Dam (IBWC 09-5220.21), immediately below Morelos Dam (IBWC 09-5220.41), and at Eleven-mile gage (IBWC 09-5221.00). The previous water-surface profile (Owen-Joyce and others, 2000) showed considerable variability in the water-surface profile between Laguna and Morelos Dams that was not represented by the linearly interpolated profile, so water-surface elevation measurements were made in this reach. The measurements were made at lower discharges than specified for the updated accounting surface. Corrections to water-surface elevations that account for the differences in discharge were estimated from the stagedischarge rating curves at the below Laguna Dam streamflowgaging station and the below Yuma Main Canal Wasteway streamflow-gaging station. Between Laguna Dam and the below Yuma Main Canal Wasteway streamflow-gaging station, the updated accounting surface discharge was $716 \mathrm{ft}^{3} / \mathrm{s}$, whereas the discharge measured during the water-surface elevation measurements was $440 \mathrm{ft}^{3} / \mathrm{s}$. The water-surface profile between Laguna Dam and the below Yuma Main Canal Wasteway streamflowgaging station was defined in the ground-water model by the measurements plus a correction of $0.8 \mathrm{ft}$, based on the stagedischarge rating curve at the below Laguna Dam streamflowgaging station. In the reach between the below Yuma Main Canal Wasteway streamflow-gaging station and Morelos Dam, the discharge specified for the updated accounting surface was 1,526 $\mathrm{ft}^{3} / \mathrm{s}$. The discharges measured during the water-surface elevation measurements were 670 and $778 \mathrm{ft}^{3} / \mathrm{s}$. The water-surface profile between the below Yuma Main Canal Wasteway streamflowgaging station and the above Rockwood Weir streamflow-gaging 
station was defined in the ground-water model by the measurements plus a correction of $1.2 \mathrm{ft}$, based on the stage-discharge rating curve at the below Yuma Main Canal Wasteway streamflow-gaging station and the average of the measured discharges in that reach. An analysis of streamflow-gaging station records by Jeffrey C. Addiego (Bureau of Reclamation, written commun., 2008) provided the water-surface elevation at the above Rockwood Weir streamflow-gaging station. Just above and below Morelos Dam and at the Eleven-mile gage (at river mile 18.8), the average monthly high stages at the IBWC streamflowgaging stations were used to establish the water-surface elevations. Below Eleven-mile gage, the land surface digitized along the path of the Colorado River was used as the water-surface boundary condition in the ground-water flow model.

\section{Drainage Ditch Reaches}

Along reaches of the Colorado River where water is diverted for irrigation on the flood plain, drainage ditches intercept return flow to the river and the river gains water from the aquifer. In these reaches, the accounting surface is defined by using the water-surface elevation in the drainage ditches along the edge of the flood plain. Flood-plain irrigation with diverted Colorado River water causes a higher ground-water level under the flood plain because irrigation water not consumptively used by crops percolates down to the water table and causes the water table to rise. There is a constant flow of irrigation with diverted river water, percolation to the drainage ditches or river, and flow in the drainage ditches to the river. Interception of the percolated irrigation water by a network of drainage ditches connected to the Colorado River keeps the water table from rising up into the root zone and this level is higher than it would be if controlled by the river. Because water in the drainage ditches is considered Colorado River water for accounting surface purposes, it warrants the same level of protection from depletion without an entitlement as water in the Colorado River and stored in reservoirs. Where drainage ditches intercept percolated irrigation water, the water-surface elevations in the drainage ditches were used to define the accounting surface. Drainage ditches along the edge of the flood plain could not be used in the Yuma area because the elevation of the water surface is controlled mainly by recharge from the unlined canals that are above the flood-plain elevation and run parallel to the edge of the flood plain rather than by percolation from irrigation on the flood plain. Water-surface elevations in the drainage ditches were determined from USGS measurements in 2007 and 2008.

\section{Ground-Water Flow Models}

In the previous studies, the accounting surface was handdrawn using hydrologic judgment to extend water-surface elevations into the river aquifer based on the shape of the river aquifer. This study refines that procedure by using simple physically based steady-state numerical models to calculate the updated accounting surface.
The river aquifer was represented as a single model layer of uniform aquifer thickness and spatially invariant or constant transmissivity. Because transmissivity is the product of the aquifer thickness and hydraulic conductivity, hydraulic conductivity in the model also is constant. With the assumption of a spatially invariant or constant transmissivity throughout the model domain, the governing equation of steady-state flow in two dimensions is:

$$
\frac{\partial^{2} h}{\partial x^{2}}+\frac{\partial^{2} h}{\partial y^{2}}=0
$$

where $h$ is hydraulic head and $x$ and $y$ represent Cartesian coordinates along orthogonal axes. Aquifer thickness and conductivity are not present in equation 1 ; the distribution of heads in the modeled river aquifer depends only on the aquifer boundaries and the specified water-surface elevations in the drainage ditches in the flood plain and in the Colorado River. Flow rates through the aquifer would depend on the aquifer transmissivity, but flow rates are not considered in this study.

The river aquifer adjacent to the Colorado River is unconfined. The assumption of constant transmissivity neglects spatial variations in transmissivity that would arise from the spatial variations in the vertical position of the water table. The assumption also neglects variations in transmissivity that occur from variations in the vertical position of the aquifer bottom as well as spatial variations in hydraulic conductivity. A more rigorous approach would be to use the nonlinear Boussinesq equation instead of the simpler linear Laplace equation (equation 1). That approach, however, would have required unavailable information on aquifer geometry and hydraulic properties. Use of equation 1 is in keeping with a long history in the field of ground-water hydrology of using simple linear equations with the assumption of homogeneous properties to approximate ground-water conditions and responses and is consistent with the overall parsimonious approach taken in the concept, definition, and application of an accounting surface.

The accounting surface in the four areas was modeled with MODFLOW 2000 (Harbaugh and others, 2000) using the watersurface elevations in the Colorado River and drainage ditches as constant-head boundaries. The grid spacing in the models was $0.25 \mathrm{mi}$ along model rows and columns. General characteristics of the model grids are given in table 4 and the extent of the model grids is shown in figure 1 . The path and distribution of Colorado River and drainage ditch water-surface elevations were established on the model grids using the RIVGRID program (Leake and Claar, 1999). The water-surface elevations defined by RIVGRID were then incorporated into the models as nodes with a constant head.

Areas of the river aquifer adjacent to the Colorado River for which the accounting surface was modeled include (1) Mohave Valley; (2) Parker, Palo Verde, and Cibola Valleys; (3) Imperial Dam to Laguna Dam; and (4) the Yuma area. Each area was modeled with a single horizontal layer of cells of thickness $500 \mathrm{ft}$ and hydraulic conductivity $39.2 \mathrm{ft} /$ day; however, as pointed out in the discussion of equation 1 , the model predictions of the accounting surface are independent of thickness and hydraulic 
conductivity. Tests were carried out by varying hydraulic conductivity and thickness to verify that computed head distributions were independent of these parameters. Rows and columns of the model grids were oriented in east-west and north-south directions in the UTM, Zone 11, coordinate system.

\section{Updated Accounting Surface}

The accounting surface around reservoirs was updated using a reservoir elevation. The accounting surface is set at its maximum possible level of 1,205.4 $\mathrm{ft}$ in the river aquifer around Lake Mead (fig. 4 and plate 1) and has not changed from the original accounting surface. The accounting surface is set at $644.0 \mathrm{ft}$ in the river aquifer around Lake Mohave (fig. 5 and plate 1), and at $448.7 \mathrm{ft}$ in the river aquifer around Lake Havasu (fig. 5 and plate 2 ), the current high monthly target elevations for these reservoirs. These elevations are slightly different from the high monthly target elevation used for the original accounting surface. In the river aquifer between the major reservoirs, ground-water flow models with boundary conditions set by Colorado River and drainage ditch water-surface elevations were used to contour the accounting surface. The models computed water-level elevations over the entire river aquifer; however, only contours in the river aquifer where the accounting surface exists are shown for modeled areas (figs. 4-7 and plates 1-3). The updated accounting surface is shown on maps for Mohave Valley and adjacent tributary areas (fig. 5 and plate 2); for Parker, Palo Verde, and Cibola Valleys and adjacent tributary areas (fig. 6 and plate 2); and for the Yuma area upstream and downstream from Laguna Dam and adjacent tributary areas (fig. 7 and plate 3). The model grid in the Yuma area extends to the south of the accounting surface, but only contours in the area with the accounting surface are shown.

\section{Summary}

An update of the accounting surface developed in the 1990s to identify wells outside the flood plain of the lower Colorado River that yield water that will be replaced by water from the river was required as a result of changes in the ground and surface water systems and a datum correction to the water surface elevations in drainage ditches. The updated accounting surface will be used to identify which wells need an entitlement for diversion of water from the Colorado River and need to be included in accounting for consumptive use of Colorado River water as outlined in the Consolidated Decree of the United States Supreme Court in Arizona v. California, 547 U.S.150 (2006). Contours of the original accounting surface were hand drawn based on the shape of the aquifer, water-surface elevations in the Colorado River and drainage ditches, and hydrologic judgment.

The original accounting surface was updated based on updated water-surface elevations in the Colorado River and drainage ditches, and the use of a simple, physically based ground-water flow model to calculate the accounting surface. The water-surface elevation of the Colorado River was determined for discharges specified by Reclamation. The water-surface elevations were derived from a linearly interpolated profile between USGS and Reclamation streamflowgaging stations and supplemented by IBWC streamflowgaging stations downstream from the northerly international boundary with Mexico. In addition, water-surface elevations were measured where the linearly interpolated profile deviated significantly from the water-surface profile used to develop the original accounting surface. The USGS also measured water-surface elevations in drainage ditches in the Parker, Palo Verde, and Cibola Valleys.

The accounting surface was modeled with MODFLOW 2000 (Harbaugh and others, 2000) using the water-surface elevations in the Colorado River and drainage ditches as constant-head boundaries. Reaches of the river aquifer adjacent to the Colorado River for which the accounting surface was modeled include (1) Mohave Valley, (2) Parker, Palo Verde, and Cibola Valleys, (3) Imperial Dam to Laguna Dam, and (4) the Yuma area. The development and application of computer models will make further updating of the accounting surface, if necessary, a straightforward task. In the river aquifer adjacent to reservoirs, the accounting surface was determined by a reservoir elevation specified by Reclamation.

Table 4. Properties of ground-water flow models used to compute the accounting surface for areas along the lower Colorado River.

\begin{tabular}{|c|c|c|c|c|c|}
\hline \multirow[t]{2}{*}{ Area modeled } & \multicolumn{2}{|c|}{$\begin{array}{l}\text { UTM Coordinates of northwest } \\
\text { corner of model grid', in meters }\end{array}$} & \multirow{2}{*}{$\begin{array}{l}\text { Number of } \\
\text { model rows }\end{array}$} & \multirow{2}{*}{$\begin{array}{c}\text { Number of } \\
\text { model columns }\end{array}$} & \multirow{2}{*}{$\begin{array}{c}\text { Number of } \\
\text { active cells }\end{array}$} \\
\hline & Easting & Northing & & & \\
\hline Mohave Valley & 706260.7 & 3897829.0 & 160 & 139 & 13,264 \\
\hline Parker, Palo Verde, and Cibola Valleys & 636449.1 & 3797916.0 & 329 & 388 & 87,176 \\
\hline Imperial Dam to Laguna Dam & 730975.8 & 3672261.3 & 103 & 88 & 4,702 \\
\hline Yuma Area & 640414.6 & 3691950.0 & 511 & 340 & 69,814 \\
\hline
\end{tabular}

${ }^{1}$ Universal Transverse Mercator, Zone 11 coordinates, North American Datum of 1927.

${ }^{2}$ Includes cells with computed head and constant-head cells used to represent water-surface features. 


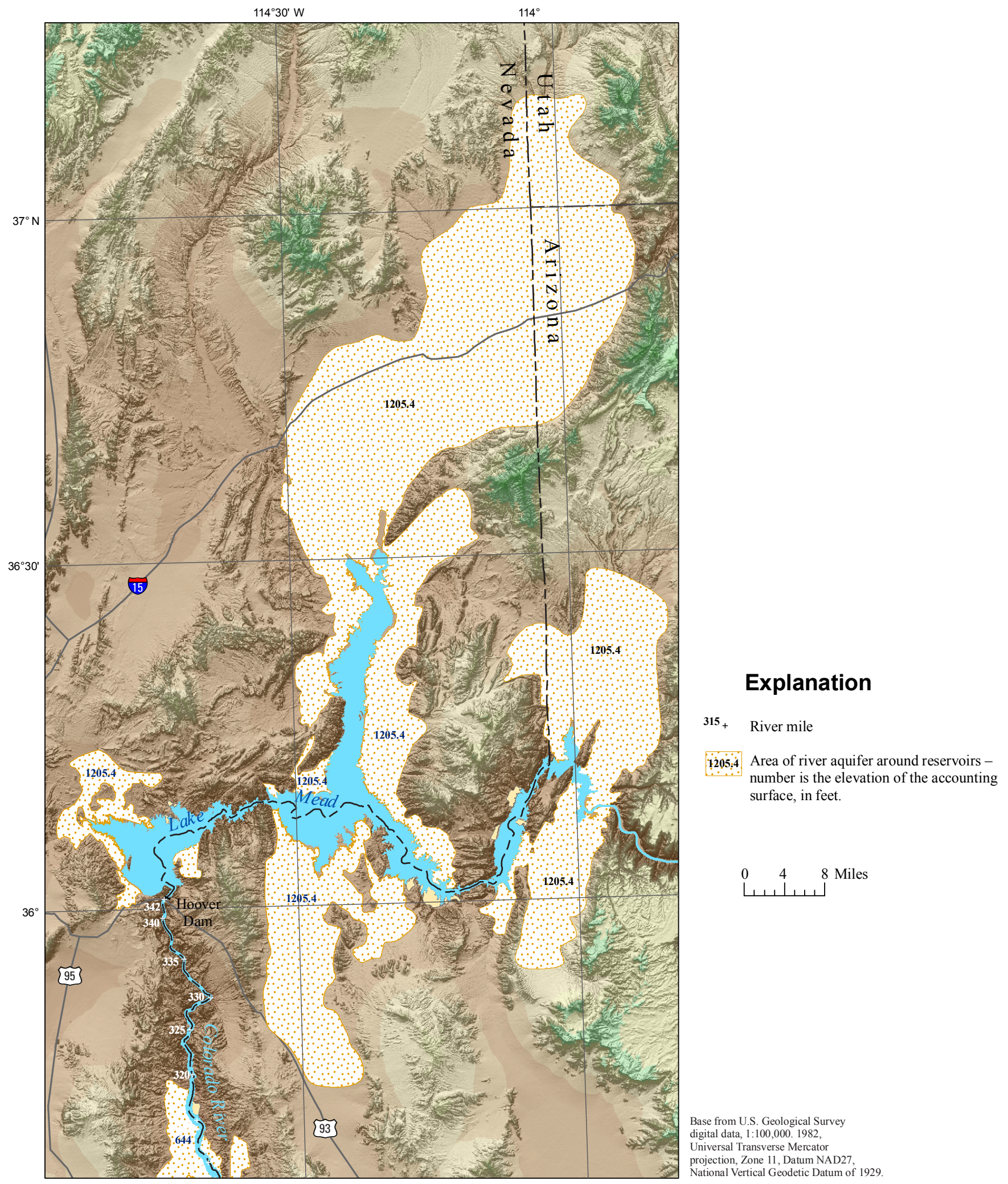

Figure 4. Map showing the accounting surface in the areas surrounding Lake Mead, Arizona, Utah, and Nevada. 


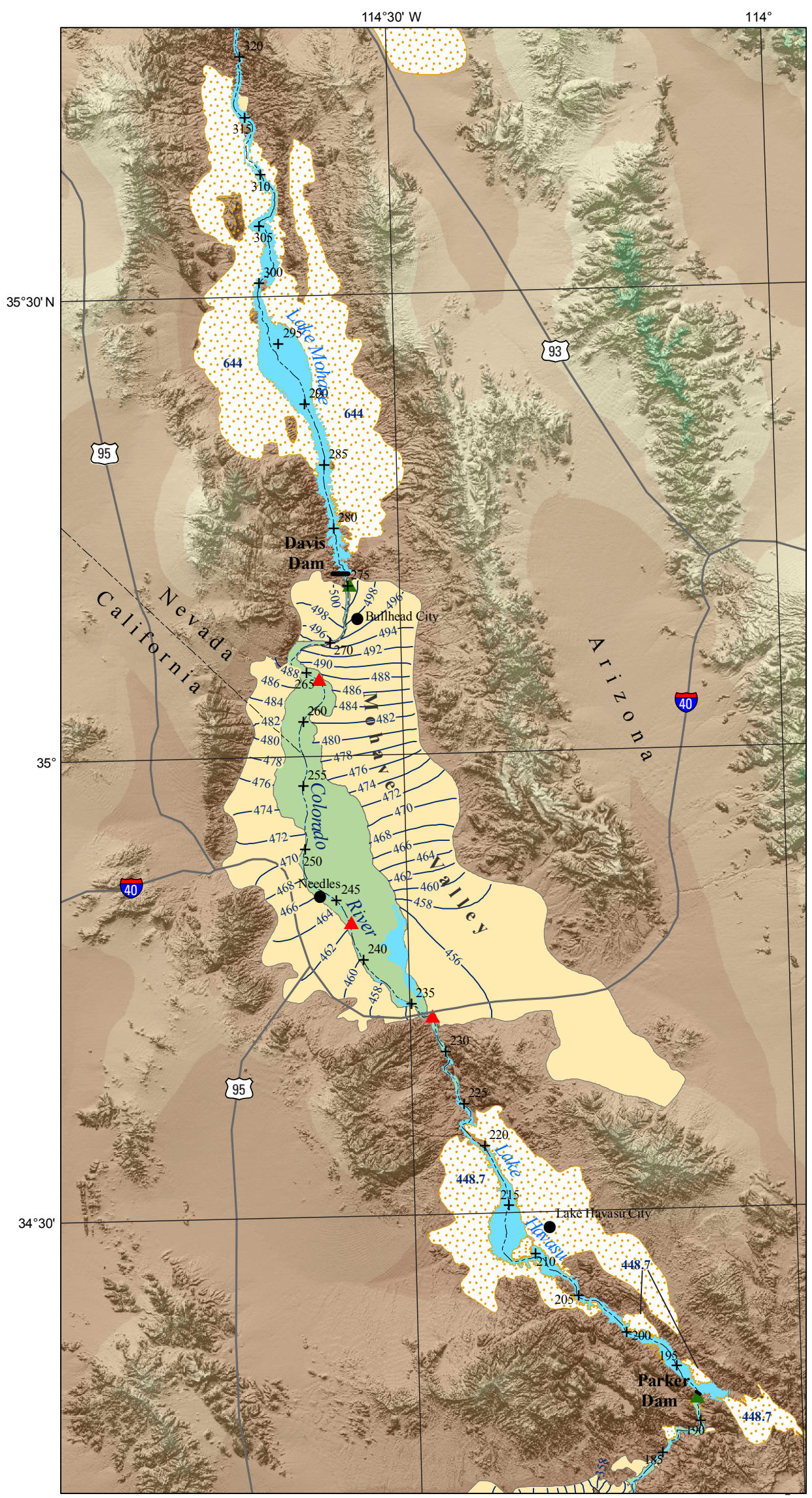

Figure 5. Map showing the accounting surface in Mohave Valley and adjacent tribu tary areas in Arizona, California, and Nevada.

\section{Explanation}

\section{$315+\quad$ River mile}

- Reclamation streamflow-gaging station

- USGS streamflow-gaging station Accounting-surface contour-Shows $458-$ equal elevation of accounting surface. Interval is 2 feet.

Area of river aquifer along river reachescontours define accounting surface, in feet. Area of river aquifer around reservoirs number is the elevation of the accounting surface, in feet.

Flood plain

$\begin{array}{lll}0 & 4 & 8 \text { Miles }\end{array}$

لـ

Base from U.S. Geological Survey

digital data, 1:100,000. 1982,

Universal Transverse Mercator

projection, Zone 11, Datum NAD27,

National Vertical Geodetic Datum of 1929. 


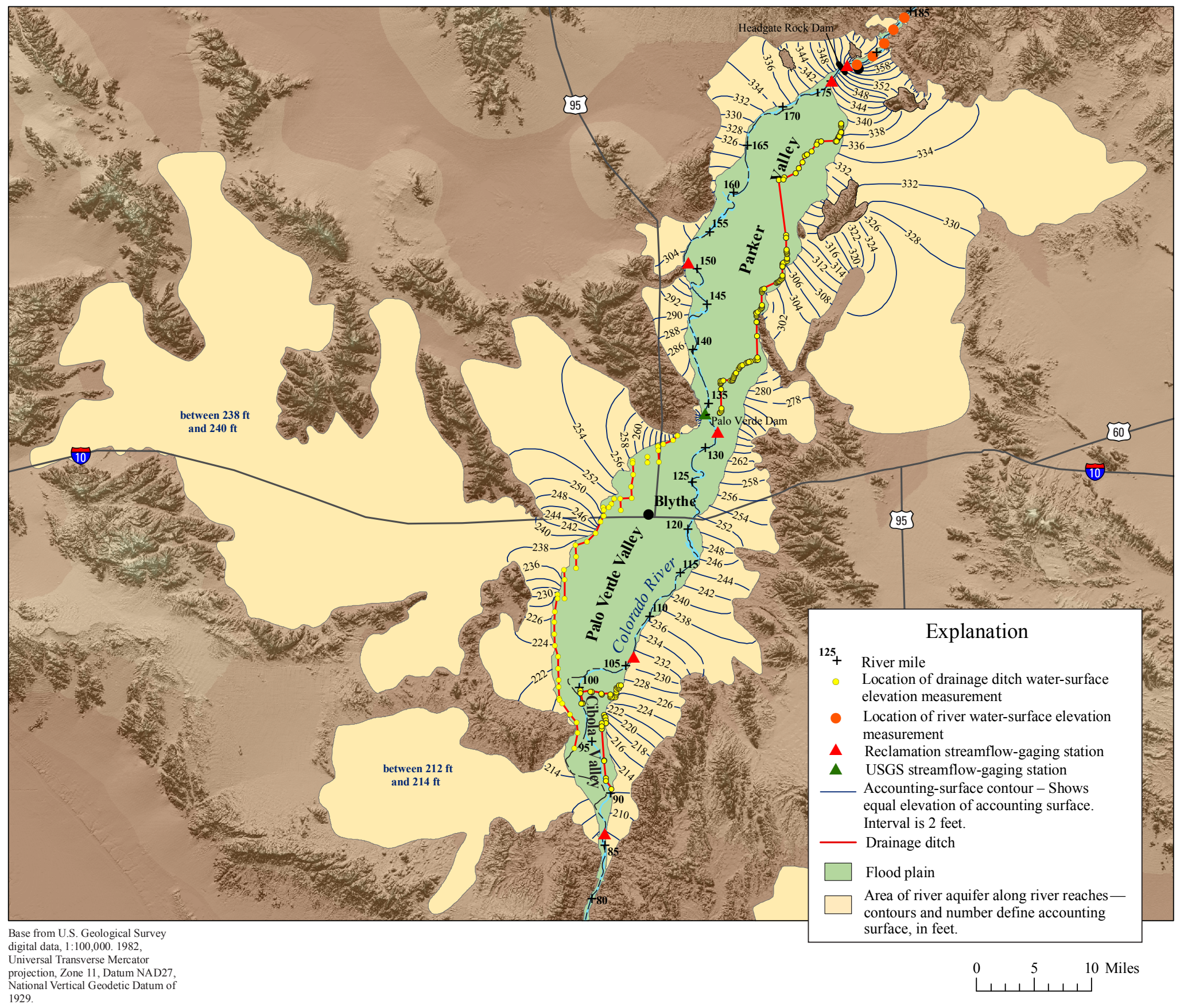

Figure 6. Map showing the accounting surface in Parker, Palo Verde, and Cibola Valleys and adjacent tributary areas in Arizona and California. 


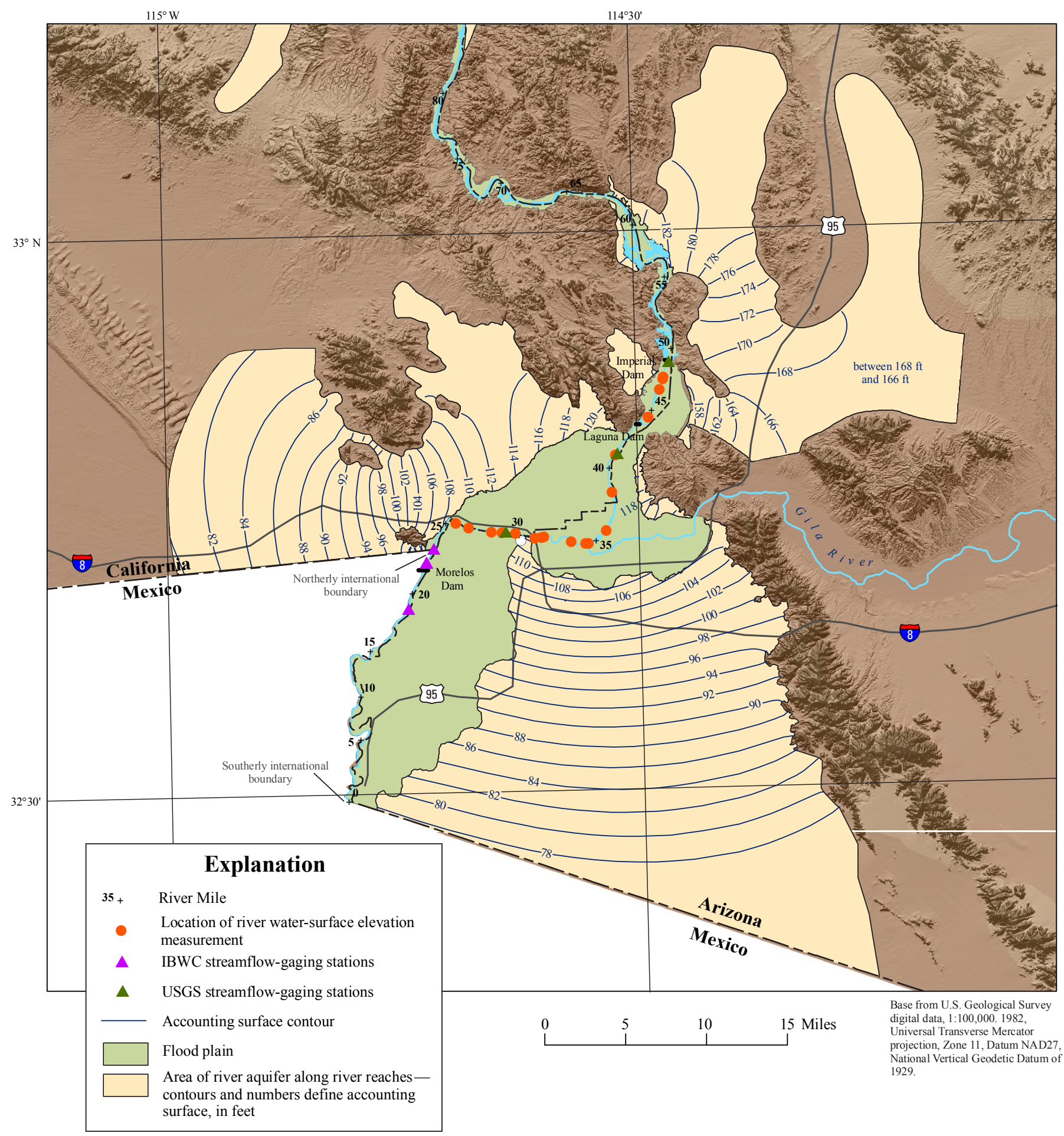

Figure 7. Map showing the accounting surface in the Yuma area upstream and downstream from Laguna Dam and adjacent tributary areas in Arizona and California. 


\section{References Cited}

Bureau of Reclamation, 2001, River miles chart: Boulder Canyon Operations Office, Lower Colorado Region, Bureau of Reclamation [http://www.usbr.gov/lc/region/pao/rvrmiles. pdf].

Dickinson, J.E., Land, Michael, Faunt, C.C., Leake, S.A., Reichard, E.G., Fleming, J.B., and Pool, D.R., 2006, Hydrogeologic framework refinement, ground-water flow and storage, water-chemistry analyses, and water-budget components of the Yuma area, southwestern Arizona and southeastern California: U.S. Geological Survey Scientific Investigations Report 2006-5135, 88 p. [http://pubs.usgs. gov/sir/2006/5135/pdf/sir20065135.pdf].

Harbaugh, A.W., Banta, E.R., Hill, M.C., and McDonald, M.G., 2000, MODFLOW-2000, the U.S. Geological Survey modular ground-water model-User guide to modularization concepts and the ground-water flow process: U.S. Geological Survey Open-File Report 00-0092, 121 p.

Leake, S.A., and Claar, D.V., 1999, Procedures and computer programs for telescopic mesh refinement using MODFLOW: U.S. Geological Survey Open-File Report 99-238, $53 \mathrm{p}$.

Metzger, D.G., 1965, A Miocene(?) aquifer in the ParkerBlythe-Cibola area Arizona and California: U.S. Geological Survey Professional Paper 525-C, p. C203-C205.

Metzger, D.G.,1968, The Bouse Formation (Pliocene) of the Parker-Blythe-Cibola area, Arizona and California: U.S. Geological Survey Professional Paper 600-D, p. D126D136.

Metzger, D.G., and Loeltz, O.J., 1973, Geohydrology of the Needles area, Arizona, California, and Nevada: U.S. Geological Survey Professional Paper 486-J, 54 p.

Metzger, D.G., Loeltz, O.J., and Irelan, Burdge, 1973, Geohydrology of the Parker-Blythe-Cibola area, Arizona and California: U.S. Geological Survey Professional Paper 486-G, 130 p. http://pubs.er.usgs.gov/usgspubs/pp/pp486G, accessed March 3, 2008.
Olmsted, F.H., Loeltz, O.J., and Irelan, Burdge, 1973, Geohydrology of the Yuma area, Arizona and California: U.S. Geological Survey Professional Paper 486-H, 227 p.

Owen-Joyce, S.J., and Wilson, R.P., 1994, Accounting for consumptive use of lower Colorado River water in Arizona, California, Nevada, and Utah: U.S. Geological Survey Fact Sheet 94-074, 2 p.

Owen-Joyce, S.J., Wilson, R.P., Carpenter, M.C., and Fink, J.B., 2000, Method to identify wells that yield water that will be replaced by water from the Colorado River downstream from Laguna Dam in Arizona and California: U.S. Geological Survey Water-Resources Investigations Report 00-4085, 3 plates, 31 p. [http://az.water.usgs.gov/pubs/pdfs/ WRIR00-4085WEB.pdf].

Remondi, B.W., 1985, Global Positioning System carrier phase-Description and use: Rockville, Maryland, National Oceanic and Atmospheric Administration Technical Memorandum NOS NGS-42, $21 \mathrm{p}$.

Spangler, L.E., Angeroth, C.E., and Walton, S.J., 2007, Application of geographic information system methods to identify areas yielding water that will be replaced by water from the Colorado River in the Vidal and Chemehuevi areas, California, and the Mohave Mesa area, Arizona: U.S. Geological Survey Scientific Investigations Report 2007-5284, $37 \mathrm{p}$.

U.S. Congress, 1948, The Hoover Dam documents: U.S. Congress, 80th, 2d session, House Document No. 717, 936 p.

U.S. Supreme Court, 2006, State of Arizona, plaintiff v. State of California, et al., defendants: U.S. Supreme Court Consolidated Decree-March 27, 2006, no. 8, original, 34 p.

Wilson, R.P., and Owen-Joyce, S.J., 1994, Method to identify wells that yield water that will be replaced by Colorado River water in Arizona, California, Nevada, and Utah: U.S. Geological Survey Water-Resources Investigations Report 94-4005, 19 plates, 36 p. [http://pubs.er.usgs.gov/usgspubs/ wri/wri944005]. 
Produced in the Western Region, Menlo Park, California Manuscript approved for publication, June 20, 2008

Text edited by James W. Hendley II

Layout by David R. Jones 
